\title{
Teacher Readiness in Implementing the Teaching of Design and Technology and Its Relationship with Self-Efficacy and Intrinsic Motivation
}

\author{
Zaleha Endot \\ Institut Pendidikan Guru Kampus Raja Melewar, \\ 70400 Seremban, Negeri Sembilan, Malaysia \\ Rahimah Jamaluddin (Corresponding author) \\ Department of Science and Technical Education, \\ Faculty of Educational Studies, Universiti Putra Malaysia, 43400 UPM Serdang, Selangor, \\ Malaysia

\begin{abstract}
Ahmad Fauzi Mohd Ayub
Department of Foundation Studies,
\end{abstract} \\ Faculty of Educational Studies, Universiti Putra Malaysia, 43400 UPM Serdang, Selangor, \\ Malaysia

\begin{abstract}
Mohd Hazwan Mohd Puad
Department of Science and Technical Education,

Faculty of Educational Studies,

Universiti Putra Malaysia, 43400 UPM Serdang, Selangor, Malaysia
\end{abstract}

Received: Oct. 8, $2021 \quad$ Accepted: Nov. 15, $2021 \quad$ Online published: Nov. 22, 2021

doi:10.5296/ijhrs.v11i4S.19234 URL: https://doi.org/10.5296/ijhrs.v11i4S.19234

\begin{abstract}
An important component of an education change begins with readiness among the implementers. Willingness to face change needs to be measured from the perspective of the
\end{abstract}


individual implementing the change, especially teachers. Therefore, this study was conducted to identify the relationship between teachers' readiness in implementing the teaching of Design and Technology (RBT) year four of the Primary School Standard Curriculum (KSSR) with self -efficacy and intrinsic motivation. This study is guided by the Wallace Reflective Model. The quantitative study of this descriptive survey involved 368 teachers of RBT fourth year KSSR subjects in Peninsular Malaysia. Cluster and simple random sampling were used to select the sample for this study. The research instrument consisted of a set of questionnaires containing 77 items. The findings of the study showed that the overall mean of teachers' readiness in terms of reasoning knowledge and PBS skills was high. The readiness of teachers in terms of PBS skills recorded a higher mean value $(\mathrm{M}=$ 3.92) compared to reasoning knowledge $(M=3.82)$. These findings give the impression that teachers are more prepared in terms of PBS skills in implementing the teaching of RBT KSSR. The results of the Pearson Correlation Test showed that there was a moderately positive relationship between the independent variables (self-efficacy and intrinsic motivation) with teachers' readiness. The findings of this study prove that the component of teachers' readiness is very important to be taken into account in the formulation of a new curriculum. Factors of self-efficacy and intrinsic motivation also need to be considered because these two variables have a significant relationship with the readiness of teachers in implementing teaching in the classroom. Therefore, this study is expected to provide guidance to policy makers and curriculum planners to pay attention to the aspect of teacher readiness when introducing new subjects.

Keywords: curriculum change, teachers' readiness, design and technology

\section{Introduction}

Along with the progress and development of Malaysia towards achieving the Vision of Shared Prosperity 2030, the education system in Malaysia has undergone several phases of change. This change can be seen through the Malaysian Education Development Plan (PPPM) 2013-2025 which has been launched to achieve improvement targets in terms of quality, equity, and access within 13 years. The Ministry of Education Malaysia (MOE) has taken the first step by introducing the Primary School Standard Curriculum (KSSR) to replace the Integrated Primary School Curriculum (KBSR) (Curriculum Development Department, 2011). KSSR is more holistic and relevant to produce a balanced human capital that can deal with current and future challenges in line with the changes in the Malaysian Education Development Plan (PPPM) 2013-2025. As a result, a new subject was also introduced, namely Design and Technology (RBT) to replace the existing subject, which normally known as Primary School Life Skills (KHSR). These changes require teachers to have high self-efficacy so that they can easily accept new ideas as a result of the changes and subsequently apply them in the teaching and facilitation process ( $\mathrm{PdPc})$. Besides, the self-efficacy of teachers, intrinsic motivation of teachers also plays an important role in the teaching process.

\subsection{Problem Statement and Limitation of the Study}

The implementation of KSSR in 2011 has created another transformation in education in the 
country. Changes in national education policy are seen to have a positive impact on the sustainability of the education system, but it is sometimes difficult for teachers to adapt to these changes. The difficulty and complexity of change causes teachers to face a dilemma between common practice and new ideas (Trombly, 2014). Various reforms of the education system contribute to the stress of teachers as they need to adapt to meet the requirements of the new system (Tajulashikin, Fazura \& Mohd Burhan, 2013).

Past findings show, teachers are not ready for the changes introduced due to several factors such as intrinsic motivation (Nirwana, 2013), found that teachers are not ready and competent enough to implement changes in smart education. Studies abroad also show a similar pattern where teachers are not fully prepared when there is a change in education in the country including studies by Joza (2015) in Saudi Arabia and Ekwueme and Meremikwu (2013) in Nigeria. In the context of fourth year RBT subjects in particular, the main changes that were emphasized were from the aspects of reasoning skills and assessment skills using PBS to implement curriculum innovation. This change certainly presents a challenge for teachers to apply it as teachers do not fully master both of these aspects.

Deci and Ryan (2000) assert that intrinsic motivation is a natural tendency and an essential element in an individual's cognitive, social and physical development. He added that through intrinsic motivation, a person develops in terms of knowledge, skills and attitudes. Intrinsically motivated individuals will be pro-active in exploring new learning and performing academic assignments on their own volition thus producing quality and creative findings (Deci \& Ryan, 2000).

Therefore, this study was conducted in more detail to examine the teachers' readiness in terms of reasoning knowledge and PBS skills. In addition, this study was also conducted to determine the relationship between teachers' readiness with self-efficacy and intrinsic motivation. However, the teacher's readiness is limited to the standard four teachers' which located in Peninsular Malaysia only.

\subsection{Objectives of the Study}

This study generally aims to identify the teachers' readiness in the implementation of RBT teaching and further examine the relationship between self-motivation and self-efficacy of teachers with their readiness in implementing RBT teaching year four KSSR. This study will answer three research questions as follows:

1. What is the teachers' readiness in terms of knowledge and skills in the implementation of teaching RBT year four KSSR?

2. Is there a significant relationship between self-efficacy and the teachers' readiness in implementing the teaching of RBT year four KSSR?

3. Is there a significant relationship between intrinsic motivation and the teachers' readiness in implementing the teaching of RBT year four KSSR? 


\section{Literature Review}

Wallace's (1991) reflective model adheres to the belief that before pursuing professional training, a teacher usually has their prior knowledge and experience relevant to his or her field of work. When following professional training, a teacher will relate the prior knowledge which he has received through experience (experiential knowledge). The two sources of knowledge are interdependent with each other to enable teachers to be better prepared to perform their professional duties. In the context of this study, RBT teachers already have knowledge through existing experience (experiential knowledge) about the basics of pedagogy as well as other factors such as self-efficacy and intrinsic motivation before implementing RBT teaching. This experience was gained through direct experience teaching other subjects before RBT was introduced.

Teachers' readiness is defined as the ability and skills of teachers to be willing to implement teaching in the classroom (Inan \& Lowther, 2010). Past studies on teachers' readiness have been conducted in Malaysia proving that teachers are not fully prepared when a change in education is implemented in the country (Jamaliah, 2014; Gopala et al., 2014; Nur-Abidah, 2013; Siti-Mardziah, 2013 \& Abu-Obaideh, 2012). There are similarities in the findings of studies conducted abroad by Joza (2015) in Saudi Arabia and Ekwueme and Meremikwu (2013) in Nigeria also show that teachers are not fully prepared when there is a change in education in the country.

A teacher's self-efficacy is a teacher's belief in his or her own ability or capacity to organize and perform a series of actions required to complete a teaching task in a specific context (Tschannen-Moran \& Woolfolk 2001). Findings of previous studies have confirmed that there is a positive association between teacher self-efficacy and teaching behaviours such as teaching practices, delivery, questioning and classroom management strategies (Tschnen-Moran \& Woolfolk, 2001; Cantrell \& Callaway, 2008; Tran, Duran, Richard \& Burchinal, 2012; Kaygisiz, Aragun \& Karaan, 2018; Ozdemir \& Ozkan, 2018: Vidwans, \& Faez, 2019).

Besides, the study of Mohamad-Sahari (2012) showed that there is a significant relationship between self -efficacy and the effectiveness of service programs in education. Casey (2011) in his study of efficacy also explained the relationship between efficacy and teachers' readiness. His study also looked at the effectiveness of self-teachers to implement differentiate instruction. Nirwana (2013) examined the factors that contribute to the teachers' readiness separately towards the implementation of Smart Education. The findings of the study show that apart from the experience of smart and interest, the effectiveness of teachers' self-efficacy also provides the largest and significant contribution to the teachers' readiness to implement smart education.

Intrinsic motivation is an internal drive and tendency to explore the inner and outer world of the individual himself (Deci \& Ryan, 2000). The study findings by Gangwani (2012) in India show that three aspects studied in intrinsic motivation namely progress, recognition and achievement make a meaningful contribution to the motivational factors. Demir (2011) found that teachers' extrinsic motivation has a direct and positive influence on student engagement. 


\section{Macrothink}

Whereas Mahani (2010) found that pleasure and satisfaction have a significant influence on the intrinsic motivation of female teachers to teach science compared to male teachers.

\section{Research Methodology}

\subsection{Research Design}

This study used a descriptive survey design to examine the relationship of teachers' readiness with self-efficacy and intrinsic motivation. Survey research is able to elaborate on issues and problems in a variety of perspectives especially those involving attitudes, views, behaviors and perceptions (Creswell, 2013). In addition, this study also examines the level of teachers' readiness in terms of reasoning knowledge and PBS skills.

\subsection{Research Sample}

The population of this study consists of RBT teachers who teach year four primary schools in Peninsular Malaysia totalling of 7089 (Education Policy Planning and Research Department, Ministry of Education Malaysia, 2016). Sample selection uses cluster and random sampling. A total of 364 study samples were calculated using the Cochran (1977) formula. However, a total of 450 sets of questionnaires were distributed to respondents by post because considering the factor of the possibility of the instrument not being returned or being returned incomplete.

\subsection{Research Instruments}

The research instrument contains 4 sections modified from the previous researcher's questionnaire. Section A contains 11 items for demographic information. Section B contains 21 items modified from Adediwura's (2012) questionnaire using a 5-point Likert scale. Section C contains 24 items modified from the Teachers' Sense of Efficacy Scale questionnaire developed by Tschannen-Moran and Woolfolk (2001) with a 9-point Likert scale. Next Part D consisted of 21 items modified from the Intrinsic Motivation Inventory (IMI) questionnaire developed by Deci and Ryan (1985) using a 7-point Likert scale.

\subsection{Validity and Reliability}

For the purpose of content validity, questionnaires were sent to seven experts in related fields before the pilot study was conducted. All suggestions, improvements and expert agreement on the suitability of the content and scale used in the survey instruments are taken into account to ensure the validity of the research instruments. Instrument reliability was measured using the $\alpha$ coefficient as recommended by Creswell (2013). The overall Cronbach's Alpha $(\alpha)$ value of the instrument was 0.95 .

\subsection{Data Analysis}

The analysis of research data was carried out in two stages, namely analysis using descriptive statistics and inferential statistics. Descriptive statistical analysis was used to measure the level of teachers' readiness to implement the teaching of RBT year four KSSR. While Pearson correlation inferential statistics were used to measure the relationship between teachers' readiness with self-efficacy and intrinsic motivation. The software used to analyse 
the study data was the Statistical Package for Social Science (SPSS).

\section{Findings}

\subsection{Teachers' Readiness in Implementing the Teaching of RBT Year Four KSSR}

The descriptive analysis in Table 1 showed that the overall mean for the aspect of reasoning knowledge was $3.82(\mathrm{SP}=.57)$. This gives the impression that the respondents have a high level of reasoning knowledge and are ready to implement the teaching of RBT year four KSSR. Items with the highest mean values indicated that respondents clearly understood the goals of RBT subjects $(\mathrm{M}=4.15, \mathrm{SP}=.49)$. Furthermore, respondents were also seen to be able to master the topics in RBT subjects $(\mathrm{M}=3.88, \mathrm{SP}=.60)$ and be able to guide students while teaching RBT subjects so that they have reasoning skills $(\mathrm{M}=3.84, \mathrm{SP}=.59)$.

Meanwhile, the lowest mean refers to the respondents' agreement on their knowledge of the types of reasoning skills to be used when teaching RBT $(\mathrm{M}=3.68, \mathrm{SP}=.62)$. This finding means that the willingness of respondents in terms of knowledge of the types of reasoning skills to be used when teaching RBT is still weak compared to other aspects of reasoning knowledge.

Table 1. Readiness of Teachers in Terms of Reasoning Knowledge

\begin{tabular}{l|l|c|c|}
\hline \multicolumn{1}{c}{ Item } & \multicolumn{1}{c}{ Mean } & $\begin{array}{c}\text { Standard } \\
\text { Deviation }\end{array}$ \\
\hline B1 & \multicolumn{1}{c}{ I clearly understand the objectives of RBT subjects } & 4.15 \\
\hline B2 & I have mastered the topics in the RBT subject & 3.88 & .60 \\
\hline B3 & $\begin{array}{l}\text { I clearly understand the meaning of reasoning as an } \\
\text { additional element when teaching RBT }\end{array}$ & 3.80 & .56 \\
\hline B4 & $\begin{array}{l}\text { I am knowledgeable of the basics reasoning skills to } \\
\text { use when teaching RBT }\end{array}$ & 3.80 & .56 \\
\hline B5 & $\begin{array}{l}\text { I am knowledgeable in the types of reasoning skills to } \\
\text { use when teaching RBT }\end{array}$ & 3.68 & .62 \\
\hline B6 & $\begin{array}{l}\text { I am knowledgeable in using reasoning skills in } \\
\text { problem solving when teaching RBT }\end{array}$ & 3.74 & .60 \\
\hline B7 & $\begin{array}{l}\text { I am knowledgeable in using reasoning skills in } \\
\text { decision making while teaching RBT }\end{array}$ & 3.76 & .56 \\
\hline B8 & $\begin{array}{l}\text { I am knowledgeable in using teaching techniques that } \\
\text { promote students' reasoning skills when teaching RBT }\end{array}$ & 3.76 & .57 \\
\hline B9 & $\begin{array}{l}\text { I am knowledgeable in planning teaching activities } \\
\text { that involve reasoning skills when teaching RBT }\end{array}$ & 3.82 & .56 \\
\hline B10 & $\begin{array}{l}\text { I am able to guide students to have reasoning skills } \\
\text { when teaching RBT }\end{array}$ & 3.84 \\
\hline
\end{tabular}

Table 2 displays the mean values for aspects of school-based assessment skills (SBA). The overall mean value from the aspect of PBS skills was $3.92(\mathrm{SP}=.58)$. This value indicates 
that the respondents have moderately high PBS skills. The item with the highest mean value $(\mathrm{M}=4.06, \mathrm{SP}=.51)$ was the respondent who was skilled in instructing students to perform the task correctly. Furthermore, the respondents were also found to be skilled in explaining the task criteria $(\mathrm{M}=4.01, \mathrm{SP}=.55)$ and also skilled in monitoring students performing coursework $(\mathrm{M}=4.01, \mathrm{SP}=.56)$. However, the findings show that the respondents are still not proficient in each of the elements that must be present in the RBT coursework $(M=3.74$, $\mathrm{SP}=.60)$. The findings also show that the readiness of teachers in terms of PBS skills is higher than reasoning knowledge. This gives the impression that the respondents are more prepared in terms of PBS skills in implementing the teaching of RBT year four KSSR compared to reasoning knowledge.

Table 2. Teachers' Readiness in Terms of PBS Skills

\begin{tabular}{|c|c|c|c|}
\hline \multicolumn{2}{|r|}{ Item } & \multirow{2}{*}{$\begin{array}{l}\text { Mean } \\
3.91\end{array}$} & \multirow{2}{*}{$\begin{array}{l}\text { Standard } \\
\text { Deviation } \\
.57\end{array}$} \\
\hline B11 & $\begin{array}{l}\text { I am proficient in the interpretation of proficiency level } \\
\text { (TP) of RBT subjects }\end{array}$ & & \\
\hline B12 & $\begin{array}{l}\text { I am proficient in every element that should be present } \\
\text { in RBT course work }\end{array}$ & 3.74 & .60 \\
\hline B13 & $\begin{array}{l}\text { I am skilled in assessing students' coursework } \\
\text { according to the level of mastery (TP) set in the subject } \\
\text { RBT }\end{array}$ & 3.88 & .60 \\
\hline B14 & $\begin{array}{l}\text { I am skilled in explaining the criteria of RBT course } \\
\text { work assignments before being given to students }\end{array}$ & 4.01 & .55 \\
\hline B15 & $\begin{array}{l}\text { I am skilled in monitoring students to perform RBT } \\
\text { coursework according to the set criteria }\end{array}$ & 4.01 & .56 \\
\hline B16 & $\begin{array}{l}\text { I am skilled in instructing students on RBT course work } \\
\text { assignments according to correct procedures }\end{array}$ & 4.06 & .51 \\
\hline B17 & $\begin{array}{l}\text { I am skilled in guiding students to obtain the highest } \\
\text { level of mastering (TP) in RBT coursework }\end{array}$ & 3.86 & .63 \\
\hline B18 & $\begin{array}{l}\text { I am skilled at determining the highest level of } \\
\text { mastering that a student can achieve in RBT } \\
\text { coursework }\end{array}$ & 3.82 & .62 \\
\hline B19 & $\begin{array}{l}\text { I am skilled at assessing each student as they go } \\
\text { through the process in RBT coursework }\end{array}$ & 3.96 & .59 \\
\hline B20 & $\begin{array}{l}\text { I am skilled in assessing aspects that need to be } \\
\text { assessed in RBT coursework }\end{array}$ & 3.94 & .59 \\
\hline \multirow[t]{2}{*}{$\mathrm{B} 21$} & I am skilled at evaluating all students' RBT course work & 3.96 & .59 \\
\hline & $\begin{array}{ll} & \text { Overall mean } \\
\end{array}$ & 3.92 & .58 \\
\hline
\end{tabular}

4.2 The Relationship between Self-Efficacy and Intrinsic Motivation with Teachers 'Readiness in Implementing the Teaching of RBT Year Four KSSR

Pearson Correlation test analysis (Table 3) showed that there was a moderately positive 
significant relationship between self-efficacy $(r=.48)$, intrinsic motivation $(r=.48)$ with the teachers' readiness to implement the teaching of RBT year four KSSR. Therefore, H1 and H2 cannot be rejected. This gives the impression that an increase in self-efficacy and intrinsic motivation will increase the teachers' readiness in implementing the teaching of RBT year four KSSR.

Table 3. Pearson Correlation Test Results

\begin{tabular}{|c|c|c|c|}
\hline \multicolumn{1}{c}{ Variables } & Readiness & Self -Efficacy & $\begin{array}{c}\text { Intrinsic } \\
\text { Motivation }\end{array}$ \\
\hline Readiness & 1 & $.479^{* *}$ & $.481^{* *}$ \\
\hline Self -Efficacy & $.479^{* *}$ & 1 & $.450^{* *}$ \\
\hline $\begin{array}{c}\text { Intrinsic } \\
\text { Motivation }\end{array}$ & $.481^{* *}$ & $.450^{* *}$ & 1 \\
\hline
\end{tabular}

** Significant correlation at confidence level $\mathrm{p}<0.05$

\section{Discussion}

The findings of the study showed that the mean score for the level of teachers' readiness in terms of reasoning knowledge and PBS skills in the implementation of RBT teaching is at a high level. The findings are different from the findings of Maizura (2010) which found that the level of teachers' readiness is low. Besides, the study proves that the teachers' readiness by Abu-Obaideh (2012) is at a moderate level. Similarly, the findings of Norazilawati et. al., (2014), they also found that the level of teachers' readiness in terms of knowledge and skills is at a moderate level. In addition, the findings of abroad studies on the teachers' readiness to implement the new curriculum are also different. For example, the findings of Joza's (2014) study in Saudi Arabia found that most teachers are not fully prepared to teach new subjects in primary schools.

This high level of teachers' readiness indicates that teachers in Malaysia have confidence in their ability or capability to implement RBT teaching effectively. Although the teachers who teach RBT are not among the option teachers as new RBT subjects have been introduced, but through the experience of teaching KHSR subjects can help teachers understand the content of RBT more easily thereby increasing the readiness of teachers to teach RBT. These findings also support Wallace's Reflective Model which asserts that a teacher will associate the knowledge he or she receives with knowledge through experience enabling the teacher to be better prepared to perform his or her professional duties. These findings indicate that primary school teachers are always ready to accept any changes made by the MOE. The government's proposal to introduce PBS in the RBT curriculum at the primary school level is a wise move in providing students with reasoning practices through PBS skills to enable them to be prepared to enter the more challenging world of secondary school

The results of Pearson correlation test showed that there is a relationship between independent variables (self-efficacy, intrinsic motivation) with the teachers' readiness in implementing the teaching of RBT year four KSSR. These findings are in line with the study of Nirwana (2013) and Casey (2011) which proved that there is a positive and significant 
relationship between self-efficacy and intrinsic motivation with teachers' readiness. However, the findings of this study are slightly different from the study of Gok and Kabasakal (2019) had showed that intrinsic motivation has a high positive relationship with the variables studied. Although the findings of this study indicate a relationship between self-efficacy and intrinsic motivation with teachers' readiness in implementing RBT teaching only at a moderate level, this suggests that these two independent variables are important in improving teachers' readiness to teach RBT.

This finding is in line with the theory of motivation put forward by Deci and Ryan (2000) who stated that intrinsic motivation is an internal element that is not visible outwardly but can increase a person's readiness or achievement if focused. In this regard, teachers as implementers of a change need to be given incentives or continuous support from the school and the MOE to increase their readiness. Among the things that can help increase the intrinsic motivation of teachers is through recognition and appreciation of the efforts of teachers Gangwani (2012). The school can have an excellent teacher chart for each month or give a certificate as a token of appreciation for the teacher's contribution to the school. This can indirectly increase intrinsic motivation and encourage teachers to be more open, pro-active to explore new learning, creative and always ready to perform academic assignments on their own volition (Deci \& Ryan, 2000).

From the aspect of self-efficacy, the findings of this study support the recommendation of Tschannen-Moran and Woolfolk (2001) who stated that teachers' belief in their ability or capability to organize and perform a series of actions required to complete a teaching task in a specific context can help increase teachers' readiness. Teachers who believe in their own abilities can do something different and are capable of solving problems. Therefore, the school and the MOE need to provide appropriate courses or training to increase teachers' confidence in their abilities and in turn can increase the readiness to teach RBT. This has been evidenced by the findings of Casey's (2011) study found that training exposure to teaching has successfully improved teachers 'self-efficacy.

The results of this study have proved that the combination of received knowledge and knowledge gained from experience can improve teachers' readiness in performing tasks as contained in Wallace's Reflective Model. The knowledge received by teachers through the exposure course on RBT and the existing knowledge gained through the experience of teaching KHSR subjects has helped to further increase the teachers' readiness to implement RBT teaching more effectively. The MOE needs to take into account the elements of self-efficacy and intrinsic motivation in formulating a new curriculum because the findings of this study prove that these two elements have a relationship with the teachers' readiness in implementing RBT teaching.

\section{Conclusion}

The implementation of a new curriculum or new subject requires a high level of commitment from educators. The findings of this study have proven that the teachers' readiness is an important factor that determines the success of a change. In fact, these findings have proven that self-efficacy and intrinsic motivation are very significant variables in improving teachers' 
readiness to implement RBT teaching and learning. All the results and findings of this study can be used as a guide in developing appropriate training programs to provide teachers who can meet the needs of educating students effectively. Therefore, the findings of this study are very meaningful and can be utilized and applied by various parties, especially those involved in efforts to formulate the new curriculum.

\section{References}

Abu-Obaideh, S. S. A., Bakar, A. R., Hamzah, R., \& Asmiran, S. (2012). Effect of Demographic Characteristics, Educational Background and Supporting Factors on ICT Readiness of Technical and Vocational Teachers in Malaysia. International Educational Studies, 5(6), 229-243. https://doi.org/10.5539/ies.v5n6p229

Adediwura, A. A. (2012). Teachers' Perception of SchoolBased Assessment in Nigerian Secondary Schools. Mediterranean Journal of Social Sciences, 3(1), 99-109.

Bahagian, P. K. (2011). Buku Panduan Kurikulum Standard Sekolah Rendah (KSSR). Kementerian Pelajaran Malaysia.

Cantrell, S. C., \& Callaway, P. (2008). High and low implementers of content literacy instruction: Portraits of teacher efficacy. Teaching and Teacher Education, 24, 1739-1750. https://doi.org/10.1016/j.tate.2008.02.020

Casey, M. (2011). Perceived efficacy and preparedness of beginning teachers to differentiate instruction (Doctoral dissertation). ProQuest Dissertations and Theses.

Cochran, W. G. (1977). Sampling techniques. (3rd ed.). New York: John Wiley \& Sons.

Deci, E. L., \& Ryan, R. M. (2000). Intrinsic Motivation and Self-determination of Human Behavior. New York: Plenum.

Demir, K. (2011). Teachers' Intrinsic and Extrinsic Motivation as Predictors of Student Engagement. e-Journal of New World Sciences Academy Education Sciences, 6(2), 1397-1409.

Ekwueme, C. O., Meremikwu, A. \& Kalu, N. (2013). The National Mathematics Curriculum for BEP (Basic Education Programme) and the MDG (Millennium Development Goals) for Mathematics teachers in Nigeria: teachers' perception and readiness. US-China Education Review, 3(3), 163-171.

Gangwani, S. (2012). Intrinsic and extrinsic motivational factors affecting teachers-a study with respect to Indore region. International Journal of Organizational Behaviour \& Management Perspectives, 1(1), 1-7.

Gok, B., \& Kabasakal, K. A. (2019). Analysing prospective teachers' self-efficacy belief, teaching motivation and attitudes towards teaching from the perspective of several variables. Journal of Education and Instruction, 9(4), 1081-1112. https://doi.org/10.14527/pegegog.2019.035

Gopala, K. S., Roszainora, S., Nor Zaitolakma, A. S., Raja, N., Huda, R. Z., Azyanee, L., 


\section{Ml Macrothink}

International Journal of Human Resource Studies

ISSN 2162-3058

2021, Vol. 11, No. 4S

Thenmolli, V., \& Haslina, C. N. (2014). Teachers' knowledge and issues in the implementation of school-based assessment: a case of school in Terengganu. Asian Social Science, 10(30), 186-194. https://doi.org/10.5539/ass.v10n3p186

Inan, F. A., \& Lowther, D. L. (2010). Factor affecting technology integration in K-12 classroom: a path model. Educational Technology Research Development, 58, 137-154. https://doi.org/10.1007/s11423-009-9132-y

Jamaliah, J. (2014). Kesediaan Guru Kolej Vokasional Dalam Pengajaran Amali Teknologi Elektronik di Negeri Pahang. Tesis tidak diterbitkan, Universiti Tun Hussein Onn.

Joza F. A. (2015). Saudi EFL teachers' readiness and perceptions of young learners teaching at elementary school. English Language Teaching, 8(2), 86-100. https://doi.org/10.5539/elt.v8n2p86

Kaygisiz, S., Anagun, S. S, \& Karahan, E. (2018). The Predictive Relationship between Self-Efficacy Levels of English Teachers and Language Teaching Methods. Eurasian Journal of Educational Research, 78, 183-202.

Mahani R. (2010). Science Teachers' Motivation to Teach: Intrinsic Factors. Brunei International Journal of Science and Mathematics Education, 2(1), 16-31.

Maizura Y. (2010). Tahap Kesediaan Guru Terhadap Pengetahuan Kandungan Pedagogi Pendidikan Sivik dan Kewarganegaraan Tingkatan Satu. Tesis yang diterbitkan, Universiti Putra Malaysia.

Muhamad-Sahari N. (2012). Sense of Efficacy Among Secondary School Teachers in Malaysia. Asia Pasific Journal of Education, 21(1), 66-74. https://doi.org/10.1080/02188791.2001.10594643

Nirwana, M. R. (2013). Faktor Peramal Terhadap Kesediaan Guru Sekolah Rendah Kluster Dalam Melaksanakan Pendidikan Pintar Cerdas di Malaysia. Tesis PhD yang tidak diterbitkan, Universiti Putra Malaysia.

Norazilawati, A., Noh, N. M., Hamzah, M., Nik-Yusuf, N-A., \& Omar, R. (2014). Jurnal Pendidikan Sains \& Matematik Malaysia, 4(1), 81-96.

Nur-Abidah T. (2013). Kesediaan Guru Tingkatan Satu Melaksanakan Pentaksiran Berasaskan Sekolah di Daerah Tawau. Tesis tidak diterbitkan. Universiti Malaysia Sabah.

Ozdemir, N., \& Ozkan, G. (2018). The Investigation of the Relationship Between Physical Education and Sports Teacher Candidates' Communication Skills and Their Teacher Self-Efficacy Perceptions. Journal of History School, XXXIII, 1139-1156. https://doi.org/10.14225/Joh1231

Salkind, N. J. (2017). Exploring Research (7th ed). New Jersey, USA: Pearson Educational International.

Siti-Mardziah A. (2013). Kesediaan Guru Sekolah Menengah Agama Terhadap Penggunaan Teknologi Maklumat (ICT) dan Komunikasi dalam Pengajaran dan Pembelajaran. Tesis tidak 


\section{Macrothink \\ International Journal of Human Resource Studies \\ ISSN 2162-3058 \\ 2021, Vol. 11, No. 4S}

diterbitkan, Universiti Tun Hussein Onn.

Tajulashikin, J., Fazura m. N., \& Muhd-Burhan I. (2013). Faktor-faktor Penentu Stress dalam Kalangan Guru-guru: Satu Kajian di Sekolah Rendah Mubaligh di Kuala Lumpur. Jurnal kurikulum dan pengajaran Asia Pasifik, 1(2), 1-11.

Tran, N. A., Schneider, S., Duran, L., Conley, A., Richland, L., \& Burchinal, M., et. al (2012). The Effects of Mathematics Instruction Using Spatial Temporal Cognition on Teacher Efficacy and Instructional Practices. Computers in Human Behavior, 28, 340-349. https://doi.org/10.1016/j.chb.2011.10.003

Trombly, C. E. (2014). School and complexity. An International Journal of Complexity and Education, 11(2), 40-58. https://doi.org/10.29173/cmplct19017

Tschannen-Moran, M., \& Woolfolk Hoy, A. (2001). Teacher Efficacy: Capturing an elusive construct. Teaching and Teacher Education, 17(7), 783-805. https://doi.org/10.1016/S0742-051X(01)00036-1

Vidwans, M., \& Faez, F. (2019). Teaching in Linguistically and Culturally Diverse Classrooms in Canada: Self-Efficacy Perceptions of Internationally Educated Teachers. Tesl Canada Journal, 36, 48-67. https://doi.org/10.18806/tesl.v36i2.1313

Wallace, M. J. (1991). Training Foreign Language Teachers. Cambridge: Cambridge University Press.

\section{Copyright Disclaimer}

Copyright for this article is retained by the author(s), with first publication rights granted to the journal.

This is an open-access article distributed under the terms and conditions of the Creative Commons Attribution license (http://creativecommons.org/licenses/by/4.0/). 